\title{
Borrower Risk and the Price and Nonprice Terms of Bank Loans
}

\author{
Philip E. Strahan \\ Banking Studies Function
}

October 1999

\begin{abstract}
Banks are in the business of lending to risky and hard-to-value businesses. This paper show that both the price and non-price terms of bank loans reflect observable components of borrower risk. As expected, riskier borrowers -- smaller borrowers, borrowers with less cash, and borrowers that are harder for outside investors to value -- pay more for their loans. In addition, the non-price terms of loans are systematically related to pricing; small loans, loans that are secured, and loans with relatively short maturity carry higher interest rates than other loans, even after controlling for publicly available measures of risk. This suggests that banks use both the price and non-price terms of loans as complements in dealing with borrower risk. To validate this interpretation, I also show that observably riskier firms face tighter non-price terms in their loan contracts. Loans to small firms, firms with low ratings, and firms with little cash available to service debt, for example, are more likely to be small, to be secured by collateral, and to have a short contractual maturity. Larger and more profitable firms are able to borrow on better terms across all three of these non-price dimensions.
\end{abstract}

I thank Rebecca Demsetz, Fred Herriman, Beverly Hirtle, Randy Kroszner, Hamid Mehran and Lawrence White for comments and Ravi Bhasin and Jennifer Poole for excellent research assistance. The opinions expressed in the paper are mine and do not necessarily reflect the opinions of the Federal Reserve Bank of New York or the Federal Reserve System. 


\section{Introduction}

Businesses have a difficult time raising capital when their prospects are difficult to judge by outsiders. This asymmetric information problem creates a dilemma for potential lenders. Because low quality borrowers are more likely to default, their demand for credit is less sensitive to interest rates than high quality borrowers. Thus, borrowers willing to accept a high interest rate will tend to be lower quality than average. If this adverse selection effect is sufficiently powerful, credit may be rationed in equilibrium. That is, some borrowers may not be able to get credit at any price. ${ }^{1}$ Asymmetric information also worsens moral hazard problems. Borrowers have poor incentives to maximize the value of the lender's stake in the business, and without reliable information lenders may have a hard time forcing borrowers to behave. Tangible or intangible capital (e.g. reputation) can help alleviate moral hazard problems because firms with more to lose may be less tempted to shirk, and they may be less tempted to substitute high risk assets for low risk ones. ${ }^{2}$

These two kinds of information problems can be reduced if lenders discern a borrower's risk and potential profitability at the outset of a relationship and then monitor the borrower over time. If creditors are diffuse, however, their incentives to engage in costly information collection and monitoring may be very weak; if I monitor, other investors may "free ride" off my efforts. Financial intermediaries (banks) overcome the "free rider" problem by holding concentrated positions in private assets. This concentration also eliminates duplication of effort. Banks central

\footnotetext{
${ }^{1}$ For a theoretical analysis of the consequences of adverse selection for lending markets, see Stiglitz and W eiss (1981).

${ }^{2}$ See, for instance, Demsetz, Saidenberg and Strahan (1998).
} 
role is to overcome information problems, thereby reducing the cost of funding businesses (See Leland and Pyle 1977, Diamond 1984, Ramakrishan and Thakor 1984, Boyd and Prescott 1986, and Allen 1990). Banks also provide value to depositors by transforming their illiquid assets (loans) into safe ( and therefore liquid) liabilities through diversification, although this paper will not emphasize this role. (See Bryant 1980, Diamond and Dybvig 1983 and Diamond 1984.) ${ }^{3}$

How do banks overcome information problems? At the outset of a relationship, banks must evaluate the risks of making a loan, which depend in part on the nature of the firm and its business, the experience of the managers, the firm's track record, and so on. Banks can control their exposure to risk by first limiting the quantity they lend. Once a loan is made, banks monitor the actions of borrowers to protect their investment. In practice, monitoring comes down to refusing to renew a loan that has reached its maturity (or "calling" a loan early when a borrower has failed to meet the terms of the loan contract), recontracting with distressed borrowers, and efficiently salvaging collateral when borrowers default. Since neither limits on the size of the amount lent nor monitoring fully eliminate risks, banks price the remaining risks through interest charges and other kinds of fees.

This paper explores empirically how banks use the non-price terms of loan contracts to help solve information problems and control risk, and how they price those risks that remain. To be specific, I explore how loan size, loan maturity, the secured status of a loan, and the interest rates and fees charged on loans vary with borrower characteristics. I also explore the interaction

\footnotetext{
${ }^{3}$ W hile I use the term "bank loan" throughout the paper, I refer more generally to private lending by financial intermediaries, including commercial banks and other depositories, investment banks, securities firms, etc. This paper does not attempt to explore the different types of loans made by different types of intermediaries. For a comparison of bank lending with lending by finance companies, see Carey, Post and Sharpe (1998).
} 
between the price and non-price terms of loans. Little is known about the empirical relationship between loan contract features and firm characteristics due to lack of data. ${ }^{4}$ Since loans are private contracts, researchers can rarely collect a large sample to study. In this paper, I use data on lending to large corporate businesses in the United States collected since the late 1980s by the Loan Pricing Corporation.

The results suggest that riskier firms and firms more prone to adverse selection and moral hazard problems -- smaller firms, firms with less cash and greater leverage, and firms that are harder for outside investors to value -- pay more when they borrow. In addition, the non-price terms of loans are systematically related to pricing; small loans, loans that are secured, and loans with relatively short maturity carry higher interest rates than other loans. This result may seem puzzling because the bank's ability to collect in default is enhanced when a loan is secured, while the likelihood that a loan ever enters default decreases as its maturity decreases. The puzzle is resolved by the following observation: banks not only charge more to risky borrowers, they also use non-price terms that facilitate monitoring (maturity) and limit losses (loan size and collateral) more intensively when borrowers are risky. The price and non-price terms of loans are jointly determined to help solve information problems; pricing, collateral, maturity and loan size are used as complementary tools to deal with borrower risk.

To validate this interpretation, I show that observably riskier firms face tighter non-price

\footnotetext{
${ }^{4}$ A $n$ exception is a recent paper by Hubbard, Kuttner, and Palia (1998). While they estimate some similar pricing relationships, their focus is on the role of bank capital and loan supply. In addition, they do not explore the interplay between loan maturity and loan size and pricing. Lown and Peristiani (1995) also find that undercapitalized banks reduced loan supply to consumers. Dennis and M ullineaux (1998) use the LPC data to explore how borrower risk characteristics are related to the likelihood that a loan is syndicated. They find that as borrower opaqueness falls, the likelihood of syndications rises.
} 
terms in their loan contracts. Loans to small firms, opaque firms, firms with low ratings, and firms with low profits and little cash available to service debt, for example, are more likely to be small, to be secured by collateral, and to have a short contractual maturity. The strong negative relationship between borrower quality and collateral runs counter to models in which adverse selection can be reduced or eliminated because low-risk firms signal their type by their willingness to risk losing collateral. (See, for example, Bester 1985, Chan and Kanatas 1985, and Besanko and Thakor 1987.) The findings here are more consistent with Rajan and Winton (1995), who present a model in which lower quality borrowers are more likely to borrow on a secured basis.

The next section describes the key contract features of bank loans in more detail. In section III, I describe the Loan Pricing Corporation data. Section IV describes how I measure borrower risk and how these are related to price and non-price terms of loans. Section V summarizes the results.

\section{Price and Non-price Terms of Bank Loans}

Most firms use debt to finance their short-term liquidity needs and to finance long-term investment. Banks lend for both of these purposes. For short-term financing, banks offer firms lines of credit (or loan commitments -- I use the terms interchangeably). Borrowers often pay a commitment fee for the option to draw a certain amount of funds from the bank on short notice. If the borrower then decides to use the funds, he pays interest on the amount drawn. Small and medium-sized firms also often establish lines of credit with banks to fund short-term working capital. Most large, highly rated US corporations now use commercial paper as their main source of short-term, unsecured funding. Commercial paper (CP) is most often issued with a maturity of 30 days and with an interest rate lower than bank loan rates. CP issuers, however, typically also 
enter into a loan commitment with a bank, known as a CP backup line of credit. ${ }^{5}$

Banks also make term loans that are typically used to finance long term investments.

Term loans work like bonds. A borrower receives a lump sum at the beginning of the contract and pays off the loan, plus interest, over time. Unlike a line of credit, term loans do not obligate the bank to provide additional credit in the future, although borrowers often roll over their debt once it reaches its contractual maturity. While large firms tend to use bonds to finance long-term investments, small and medium-sized firms tend to borrow on a term basis from banks for this purpose.

In many cases, a "deal" between a bank and a firm will be structured to include both a line of credit and a term loan. This concentration of borrowing from a single lender (or syndicate of lenders) makes sense because firms typically need both short- and long-term financing. By concentrating their borrowings in this way, the cost of determining credit worthiness and monitoring that creditworthiness over time can be shared across the two kinds of loans. If a firm received short-term credit from one lender and long-term credit from another, each would have to learn about the firm's credit quality. The borrower would ultimately bear the cost of this duplication of effort. Of course, large well-established firms may require very little of this kind of monitoring; these kinds of firms may prefer to borrow from many banks. ${ }^{6}$

Both lines of credit and term loans involve significant risks to the bank. Lines of credit,

${ }^{5}$ For an analysis of why firms use CP backup lines of credit, and when these lines are drawn, see Saidenberg and Strahan (1999).

${ }^{6}$ See Houston and James (1996) for an empirical analysis of concentration of borrowings for large firms, and Petersen and Rajan (1994) and Berger and U dell (1995) for an analysis of concentration of borrowings for small firms. 
even when they are not drawn initially, expose the bank to both liquidity risk and credit risk. The liquidity risk arises because the bank has made a promise to provide the firm funds up to a certain amount on demand over the life of the contract. Credit risk arises because the firm may draw down the lines of credit and then default. The two problems are related because the incentive to draw funds from a line of credit become greatest when borrowing from other sources becomes difficult or expensive -- that is, when the risk of default is above average. Term lending is more straightforward because it involves credit risk but not liquidity risk (except to the extent that the bank funds its illiquid loans with liquid deposits).

Banks use various kinds of contract feature to mitigate liquidity and credit risk at the outset of a lending relationship, and to enhance their ability to monitor borrowers over the course of the relationship. First, the size of the loan limits the bank's potential exposure. Thus, the size of a line of credit or term loan will reflect a firm's ability to generate cash flow. Second, risk is limited by shortening the contractual maturity of loans. Third, bank loans are often secured by collateral. Collateral reduces loan risk because the bank has a legal claim against a well-defined set of assets (or cash flows) that can strengthen its hand in bankruptcy. For instance, VanDeCastle (1999) found that recovery rates in bankruptcy for senior secured debt were about 25 percent higher than for senior unsecured debt.

Banks also use a host of other mechanisms to control risk and minimize information problems, which as a group are known as “covenants.” In general, covenants enhance a bank's ability to call a loan, often without penalty. If borrowers misbehave, for example, banks can use a covenant violation to get their money back before things get too bad. While analysts often talk about the importance of covenants as if they represent a well-defined set of contract terms, in the 
real world covenants vary substantially across loans. ${ }^{7}$ Because of this heterogeneity, I do not model statistically the relationship between borrower attributes and covenants. Nevertheless, there are some general kinds of covenants that are common and worth describing briefly. Most bank loans contain affirmative and negative covenants. Affirmative covenants require the borrower to meet certain basic standards such as making timely payments, providing accurate financial disclosure, maintaining adequate insurance, complying with applicable laws, paying taxes, etc. Negative covenants typically limit a borrower's ability to engage in asset substitution that could harm the lender. For example, negative covenants often limit acquisition activity and asset sales. Bank loans also often come with financial covenants that require the borrower to maintain sufficient cash flow to service the loan, or that limit leverage and thereby minimize the probability of future insolvency. Financial covenants also often limit the firm's ability to pay out cash dividends to shareholders.

Despite efforts to control risk through limits on size and maturity, through collateral requirements, and through the use of covenants, the risks associated with loans will still vary across firms. Banks therefore price the remaining risk. That is, loans more likely to end in default and loans where collection in default is more difficult carry higher interest rates than other loans. In the case of lines of credit, banks price both liquidity risk and credit risk through a twodimensional pricing scheme. The drawn component of a line of credit is typically priced as a mark-up over a market interest rate such as LIBOR; the mark-up reflects the riskiness of the loan. The undrawn component is priced too -- borrowers typically pay an annual commitment fee for

\footnotetext{
${ }^{7}$ Recent evidence suggests that covenants reduce borrowing costs and improves access to credit. See M organ (1995) and Standard \& Poor's (1999).
} 
the undrawn component of a line of credit. Riskier companies pay more for the option to draw down funds in the future both because they are more likely to borrow (greater liquidity risk) and because they are more like to default (greater credit risk). Some bank loan agreements tie the interest rate to key financial ratios such as the leverage ratio or the interest coverage ratio. This performance pricing feature protects the bank against increases in risk in the future and rewards the borrower for better-than-expected performance.

\section{Loan Pricing Corporation's Data on Lending}

The information on the price and non-price terms of loans comes from Dealscan, a database of loans to large firms constructed by the Loan Pricing Corporation (LPC). LPC is a private firm that collects up-to-date information on lending for its institutional clients. LPC also maintains a historical database, Dealscan, that contains information on the pricing and contract features of a large number of loans made over the past 10 years. This study covers data from 1988 through 1998. The historical data in Dealscan come primarily from SEC filings, although LPC also receives data from large loan syndicators as well as from a staff of reporters. According to LPC, most loans made to large publicly traded companies (e.g. the Forbes 500) appear in Dealscan. There is very little information, however, on lending to small and middle-market firms.

The data on Dealscan are organized by "Deal" and by "Facility". A deal defines a contract signed between a borrower and a lender (or lenders) at a particular date. Each deal is comprised of one or more facilities (loans). So, for example, a single deal could involve a term loan facility and a line of credit facility. During the $1988-98$ period, there were 57,782 facilities on Dealscan and, on average, each deal had 1.3 facilities. Most deals had just one facility, although a significant minority had two or more. Each facility is treated as one observation. 
Dealscan contains information about loans at the date of origination, but little or no information about what happens subsequently. Coverage becomes good during that late 1980s, so the sample studied here begins in 1988 . This relatively long span of time covers the recession of the early 1990s. Unfortunately, since LPC provides only information about these deals at origination, there is no way to know whether a loan reaches maturity, or whether it is paid off early.

While Dealscan has very good information on loan contract features, it has very little information about the borrower. Thus, borrower attributes come from Compustat. While Compustat is a good source for accounting data for public companies, it too has limitations -- not all public companies are represented on Compustat. In addition, there is no common identifying variable on both the Dealscan and Compustat files, so combining the data was done based on the name of the borrower. The matching procedure was conservative in the sense that only observations where there is an unambiguous match between the name on Dealscan and the name on Compustat are retained for the final dataset. As a result, borrower characteristics are only available for about 50 percent of the loans. To insure that firm attributes are not changed as a result of the loan, I measure the Compustat variables at end of the year before the signing date. So, for example, if a bank lends to a firm in July of 1996, I take that firm's financial characteristics from the end of 1995 .

Table 1 reports average values for the key loan contract features studied below for all of the facilities, for facilities where Compustat data are available, and for facilities where Compustat data are not available. In the sample of large firms covered by Dealscan, the line of credit is by far the most common type of loan -- close to 60 percent of the facilities on the dataset are of this 
type. Large firms with access to securities markets are likely to use the CP market for short-term borrowing and the bond market for long-term borrowing; these firms rely on banks mainly for contingent credit, and lines of credit fill this need. In contrast, smaller firms not covered by Dealscan are more likely to use lines of credit for their short-term financing needs and term loans for their long-term financing. Thus, the share of loans represented by lines of credit would be considerably lower than 60 percent in a randomly selected set of bank loans. While about 90 percent of the loans on Dealscan are either lines of credit or term loans, there are a small number of other kinds of facilities, including but not limited to bridge loans, standby letters of credit, leases, etc. Since these other structures are relatively uncommon, the paper focuses hereafter on just lines of credit and term loans.

Maturity, size and the share secured vary by loan type. Lines of credit tend to be larger and are less likely to be secured than term loans. ${ }^{8}$ This difference again reflects the fact that the average firm using a line of credit is larger than the average firm using a term loan; larger firms tend to be safer and more able to service their loans, so banks are willing to lend them more, and they are more willing to lend to large firms on an unsecured basis (more on this below). Lines of credit also tend to have a shorter contractual maturity than term loans, presumably because term loans generally finance long-term investment.

Average pricing also differs between lines of credit and term loans. As noted above, lines of credit have two dimensions of pricing. The borrower pays the drawn all-in spread (AIS) to the lender each year for each dollar drawn off the line of credit. The drawn AIS equals the coupon

\footnotetext{
${ }^{8} \mathrm{~N}$ ote that information on whether a loan is or is not secured by collateral is often missing on the Dealscan database. The figures reported here for the secured status of a loan pertain only to the nonmissing values.
} 
spread plus the annual fee, measured as a markup over LIBOR. ${ }^{9}$ For lines of credit, the mean drawn AIS equals 186 basis points (bps). The borrower also pays the undrawn AIS to the lender each year for every dollar of the line not drawn, equal to the commitment fee plus the annual fee. The mean undrawn AIS on lines of credit equals 33 bps. For term loans, where only the drawn AIS is relevant, the average is considerably higher than for lines of credit -- the mean equals 238 bps. The higher price paid for the typical term loan likely reflects the smaller average size of term borrowers.

The general conclusion from comparing the two sets of facilities -- those matched to Compustat and those not matched -- is that they do not differ very much. The distribution across types of loans, the average pricing for each type of loan, the average contractual maturity and the average loan size are all similar for both Compustat and non-Compustat samples. The share secured is somewhat higher in the non-Compustat sample for the lines of credit, but somewhat lower for the term loans. This is good news because it suggests that the loans that can be compared with borrower attributes look similar to the loans for which I have no information about the borrower, so the relationships estimated from the Compustat sample apply with similar force in the non-Compustat sample.

I have also checked whether the firms appearing in Dealscan are representative of all firms on Compustat. In fact, Dealscan firms are larger and more profitable than other Compustat firms that do not appear on Dealscan. (See Appendix I for details.) These data do not represent a

\footnotetext{
${ }^{9}$ W hile most loans are floating rate, some are priced off other benchmark interest rates. If a LIBOR spread is available, it is used. For cases where another benchmark is used, LPC makes the following adjustments to the drawn AIS: Prime $=+255$ bps; Cost of funds $=0$ bps; Commercial Paper $=3 \mathrm{bps}$; $\mathrm{T}$ bills $=-34$ bps; Fed Funds $=0$ bps; $M$ oney market rate $=0$ bps; Banker's acceptance $=-18$ bps; CDS $=-6$ bps.
} 
random sample of bank loans, largely because LPC's data collection procedure is skewed toward the bigger firms. Theory suggests that the most severe information problems occur at newer, smaller firms without access to public capital markets. Thus, the relationships uncovered below likely to understate the relationships one might observe with a random sample of bank borrowers.

\section{Results}

This section explores in detail the relationship between firm characteristics and the price and non-price terms of loans, as well as the relationship between these price and non-price terms. The first subsection outlines the firm characteristics of interest, and the second reports the regressions relating borrower attributes to the loan contract terms. ${ }^{10}$

\section{Firm Characteristics}

Firm Size

Larger firms are more likely to be well-established and have access to relatively stable cash flows that can service debt. Moreover, larger firms are likely to have developed a reputation over time that lessens their incentive to behave in ways that could increase the probability of experiencing financial distress. Therefore, large firms ought to be able to borrow from banks on relatively good terms. I measure size using the log of the market value of assets, equal to the sum of the market value of equity and the book value of debt. ${ }^{11}$

\section{Profits and Cash Flow}

Lenders care about profits and the presence of cash that can service debt. Firms with

\footnotetext{
${ }^{10}$ In the analysis that follows, I drop all financial companies because the set of profitability and cash flow ratios included in the regression display markedly different distributions for financial and nonfinancial firms.

${ }^{11}$ The results are similar using either the market value of equity or the book value of assets as size measures.
} 
higher levels of current profits will be able to borrow more from banks (as well as from markets).

I measure profits and cash in four ways. First, I look at the ratio of earnings before interest, taxes, depreciation and amortization (EBITDA) to total assets. Conceptually, this ratio equals the return on assets. Second, I use a measure of cash flow based on the interest coverage ratio (EBITDA divided by interest expenses). Since the coverage ratio displays a huge range, I construct an indicator variable equal to one for firms with an interest coverage ratio above 4.25 , the median value in the sample. Third, I use the ratio of sales to total assets measure of cash flow and current profitability. Fourth, I construct an indicator measuring of the availability of short term assets relative to short term liabilities based on the quick ratio (current assets - inventories / current liabilities). The high liquidity indicator equals 1 for firms with a quick ratio greater than the median value in the sample.

\section{Ratings}

Ratings agencies produce information about firm quality that can be used by any potential lender, either a bank or an investor in the bond market. ${ }^{12}$ Rated firms will likely face less severe asymmetric information problems than unrated firms due to the efforts of the ratings agencies.

Within the set of rated firms, those with higher ratings are both safer and, because there is greater precision in ratings at higher levels, less likely to suffer from adverse selection and moral hazard problems. ${ }^{13}$ I therefore include an indicator equal to one if a firm has a bond rating. I also

${ }^{12}$ In very recent years, the ratings agencies have begun rating large syndicated loans.

${ }^{13} \mathrm{~F}$ or instance, the one-year historical default probability ranges from less than one basis point for a AAA rated borrower to 18 basis points for a BBB rated borrower. For the speculative grade borrowers, the probability of default ranges from 90 basis points for BB rated borrowers to almost 2000 basis points for $\mathrm{CCC}$ rated borrowers. Also, the range in the default probability within each ratings category increases as the rating declines. See S\&P (1999). 
construct an indicator variable equal to one for firms with an speculative grade rating (S\&P rating of BB or worse).

\section{Capital Structure}

A firm's capital structure clearly concerns lenders. First, firms with high leverage, the ratio of total debt to debt plus the market value of equity, all else equal, face a greater likelihood of future insolvency. In addition, moral hazard problems are exacerbated by high leverage because most of the downside risk is assumed by the lender, while all of the upside gain goes to the borrower. Highly levered borrowers, for instance, have a greater incentive to substitute high risk assets for low risk ones after a loan, or other debt contract, is signed. Second, the priority structure of the firm's debt may influence the riskiness of a bank loan. While bank loans are generally not subordinated to other debt in a firm's capital structure, some firms finance assets directly by leasing them rather than by buying them. In these cases, the lessor's stake is fully collateralized by a well-defined asset, making their claim in bankruptcy equal to those of other senior creditors such as banks. Thus, loans to firms with a greater percentage of debt from leases will be riskier, all else equal. ${ }^{14}$

\section{Asset Opaqueness}

As noted in the introduction, firms that are more difficult for outsiders to judge impose greater adverse selection and moral hazard problems on potential lenders. I use the ratio of the market value of assets to the book value of assets to measures asset opaqueness. The market-tobook ratio is a forward-looking measure of a firm's growth opportunities. Firms have a high

\footnotetext{
${ }^{14}$ C apitalized leases are included as part of long-term debt. For an analysis of corporate debt priority, see Barclay and Smith (1995). For a specific analysis of corporate leasing policy, see M ehran, Taggart and Y ermack (1999).
} 
market-to-book ratio if investors expect high future profits. Presumably there is more uncertainty when a firm's value depends more on profit growth than on current cash flow. Today, hightechnology firms tend to have very high market-to-book ratios, whereas regulated utilities tend to have low market-to-book ratios. As a second, more backward-looking measure of asset opaqueness, I include the ratio of tangible assets, property, plant \& equipment net of depreciation plus inventories, to total assets. ${ }^{15}$

\section{Relating Firm Characteristics to Bank Loan Pricing}

Table 2 shows the basic relationships between pricing and risk in a very simple and intuitive way by reporting average pricing for loans to borrowers based on just firm size and ratings. These figures show that loan spreads decrease with borrower size and with credit quality. For example, the drawn spread on lines of credit to unrated firm is 70 basis points lower for firms with above-median total assets than for those with below-median assets (188 v. 258 basis points). For speculative grade firms, the drawn spread on lines of credit decreases even more with firm size. Loan prices also strongly reflect the borrowers' credit rating. For large borrowers, investment grade firms pay 127 basis points less then speculative grade borrowers for lines of credit, and they pay 110 basis points less for term loans. (Notice that there are almost no small borrowers with an investment grade rating.) Table 2 also shows that the average pricing for unrated firms is similar to that of firms with a speculative grade rating.

I explore the pricing relationships more fully now by estimating a reduced form regression with the loan price as dependent variables and the firm attributes as explanatory variables. I use

\footnotetext{
${ }^{15} \mathrm{H}$ immel berg and M organ (1995) argue that tangible assets reduce firm opaqueness and thereby increase a firm's access to external capital. As evidence, they show that firms with higher levels of fixed capital are more likely to have a bond rating.
} 
the logarithmic transformation of both the drawn and undrawn spreads. Beyond the firm attributes, the regressions also include year indicator variables to control for general trends in the market (e.g. business cycle factors), indicator variables for industry, and indicator variables for the purpose of the loan. ${ }^{16}$

The simple summary statistics for the variables in the regressions are reported in Table 3. Table 4 reports the pricing regressions. I estimate each regression separately on the sample of lines of credit and on the sample of term loans. Recall that lines of credit have two dimensions of pricing, the drawn AIS and the undrawn AIS, while term loans have just the drawn AIS. As expected, loan pricing reflects differences in firm size, profitability, ratings and asset opaqueness. Looking first at lines of credit, there is a very strong relationship between size and both the drawn and undrawn AIS. The drawn AIS decreases by about 2.9 percent for every 10 percent increase in assets, while the undrawn AIS decreases by about 1.3 percent for every 10 percent increase in assets. In addition, with one exception all four measures of profitability and liquidity are negatively related to both pricing variables, although the relationships are stronger for the sample of lines of credit. The exception is that the undrawn spread on lines of credit is higher at firms with relatively high levels of short-term assets relative to short-term liabilities.

Ratings and capital structure also have a very strong effect on loan pricing. Unrated borrowers pay 44 percent more than investment grade borrowers on drawn amounts, whereas the speculative grade borrowers pay about 47 percent more than investment grade borrowers. For

\footnotetext{
${ }^{16}$ Specifically, I include industry indicators based on the one-digit SIC code. The loan purpose indicators cover the following seven categories: general corporate purposes, leverage buyouts, recapitalization, asset acquisition, takeover, working capital, and debt restructuring. The omitted category includes a large number of purposes with relatively few facilities in each, such as debtor-in-possession loans, real estate loans, trade financing, etc.
} 
the undrawn spreads, the unrated borrowers pay about 46 percent more than investment grade borrowers, while speculative grade borrowers pay about 64 percent more. Firms with more leverage and firms with more lease financing also generally pay higher interest rates. A standard deviation increase in leverage, for example, is associated with a 11 percent increase in the drawn AIS and a nine percent increase in the undrawn AIS.

Harder-to-value firms also pay higher interest rates. For example, a one standard deviation increase in the market-to-book ratio is associated with a nine percent increase in the drawn spread on lines of credit and a three percent increase in the undrawn spread. Firms with more opaque investment opportunities pay higher rates on their loans. Similarly, firms with more tangible assets pay lower rates on their loans.

Pricing of term loans also reflects the same set of firm characteristics in much the same ways. Large and profitable firms pay substantially less than smaller, less profitable ones. Unrated firms and speculative grade firms pay substantially more than investment grade borrowers. Highly leveraged firms also pay higher rates on their term loans, as do more opaque firms. ${ }^{17}$

Table 5 reports the same three equations augmented with the non-price terms of the loan contract -- the log of the size of the loan, the log of the loan's contractual maturity, and an indicator equal to 1 if the loan is secured by collateral. ${ }^{18}$ These results are important because they suggest that banks use these non-price terms to help limit their risk exposure, and to help control

\footnotetext{
${ }^{17} T$ he coefficients on the year indicators suggest that spreads on bank loans peaked during the 1990-92 credit slowdown period. This increase in spreads is consistent with a reduction in loan availability, although it could also reflect an increase in risk associated with the economic slowdown.

${ }^{18}$ I have also added an indicator equal to 1 if the information on the secured status of the loan is missing. N ote that the results are quite similar if I estimate the model on only the subset of observations where the secured status is non-missing.
} 
borrower risk taking. That is, they use both the price and non-price terms of loans as complements in dealing with borrower risk.

In particular, firms facing more restrictive non-price terms pay higher interest rates. Secured loans carry interest rates 32 to 51 percent higher than unsecured loans, even though secured loans to borrowers of equivalent risk are safer due to their higher expected rates of recovery in default. ${ }^{19}$ Similarly, larger lines of credit lower interest rates, as do both lines of credit and term loans with longer maturity. One interesting exception is that lines of credit with longer maturity carry much higher undrawn spreads. This result likely reflects the fact that lines of credit provide borrowers with an option to borrow in the future, and the value of that option increases in its maturity.

\section{Relating Firm Characteristics to the Non-Price Terms of Bank Loans}

Since banks and borrowers determine the price and non-price terms of loans jointly, the regressions in Table 5 should not be interpreted as structural relationships. In principle, one would like to find instruments that, for example, would affect the probability that a loan is secured but does not enter the loan pricing equation. Under such conditions, one would expect loans that are secured (exogenously) would have lower, rather than higher, spreads. However, no such instruments are available. The strong positive relationship between collateral and pricing suggest that banks insist that weak firms borrower on a secured basis and pay high interest rates. Similarly, weaker firms seem to borrow less and pay more, and they seem to borrow on a shorter term basis and pay more. If this interpretation is right, then observably riskier borrowers ought to

${ }^{19}$ Berger and Udell (1990) find a similar result using data from the Federal Reserve's Survey of the Term of Bank Lending. 
face tighter non-price terms in their borrowing from banks. To test this proposition, I next consider the relationship between publicly available measures of risk and three non-price terms: loan size, maturity, and the secured status of the loan (Table 6).

Loan Size (Panel A)

Banks clearly lend more to larger, more profitable firms. According to the regression coefficients, a 10 percent increase in asset size leads to a seven percent increase in the size of lines of credit and a eight percent increase in term loan size. Profits, as measured by both return on assets and the sales-to-assets ratio, are also positively related to the size of lines of credit, and firms with high levels of liquid assets also receive larger lines of credit. For term loans, three of the four profit and liquidity variables remain positively related to size but become less statistically significant. $^{20}$

The public debt rating also affects loan size, even after controlling for other key financial ratios. Here, the results vary by loan type. For lines of credit, rated borrowers, both investment grade and speculative grade, receive larger loans; within the set of rated borrowers, investment grade firms receive lines of credit about 10 percent larger than speculative grade firms. In contrast, unrated term-loan borrowers receive larger loans than investment grade firms. Here demand effects could be important -- investment grade borrowers are more likely to finance their long-term investments in the bond market rather than using banks. On the other hand, even the most highly rated firms that use commercial paper for their short-term financing still use banks for backup lines of credit. Thus, in the more representative sample (i.e. the sample based on lines of credit), ratings enhance a firm's ability to borrow from banks.

\footnotetext{
${ }^{20} \mathrm{As}$ a group, the four profit variables are statistically significantly related to the size of term loans.
} 
High market-to-book firms receive smaller loans, all else equal, suggesting that banks lend less to more opaque firms. The backward-looking measure of firm opaqueness, the tangible assets ratio, is positively related to the size of lines of credit but not significantly related to the size of term loans.

Secured Status of the Loan (Panel B)

Larger, safer, and more profitable firms are less likely to secure their loans with collateral. In addition, the harder-to-value firms, as measured by the market-to-book ratio, are more likely to borrow on a secured basis. These relationships are particularly strong for the set of lines of credit, probably because the vast majority of term loans are secured in this dataset. More than 90 percent of the term loans are secured, compared to only 75 percent of the lines of credit. With so little variation to explain, it is no surprise that the latter results are rather weak.

\section{Loan Maturity (Panel C)}

Like loan size and secured status, loan maturity reflects borrower risk. This makes sense if maturity is another way banks limit their risk exposure and strengthen their ability to monitor borrowers and thereby mitigate information problems. Banks put smaller, less profitable, and more opaque borrowers (as measured by the market-to-book ratio) on a shorter leash. These borrowers must go back to the bank more often than larger, better established firms to prove that their prospects remain bright. A 10 percent increase in size, for example, leads to a little less than a one percent increase in loan maturity, and a one standard deviation increase in return on assets leads to a four to six percent increase in maturity. While the size effect may seem weak, remember that a 10 percent change in assets is a rather small. A one standard deviation change in both asset and market capitalization leads to a 16 percent increase in maturity. The effect of the 
ratings indicators on loan maturity again probably represents demand-side influences. Both unrated and speculative grade firms borrower on a longer term basis than investment grade firms, probably because the investment grade firms have better and cheaper access to credit from the securities markets.

\section{Conclusions}

The results as a whole support the idea that banks structure their loan contracts to control their risk exposure and to facilitate their ability to monitor borrowers over time. Larger and more profitable firms are safer and in a better position to service their debt than other firms; they also have less incentive to engage in asset substitutions harmful to the bank, both because they have better established reputations and thus more to lose, and because they are more easily valued. Such firms borrow more, they pay lower interest rates, and their loans have a longer maturity and are less likely to be secured by collateral than smaller, less profitable firms. Similarly, firms with more opaque assets -- those with high market-to-book ratios and low levels of tangible assets -face more restrictive loan contracts. These firms borrow on a shorter term basis, and their loans are more likely to be secured than firms with more predictable prospects. These hard-to-value firms also appear to face high interest rates on their bank loans.

Taken together, the results suggest that banks (and other private lenders) use a variety of contract features beyond the obvious ones (price and quantity lent) to control adverse selection and moral hazard problems. Both loan maturity and the use of collateral reflect borrowers' underlying asymmetric information problems. In addition, bank loans with tighter non-price terms carry higher interest rates. Further study of the many other kinds of contract features, collectively known as "covenants," is needed to enhance our understanding of how private debt solves 
information problems. 


\section{References}

Allen, Franklin, 1990, "The Market for Information and the Origin of Financial Intermediation," Journal of Financial Intermediation 1, 3-30.

Barclay, Michael J. and Clifford W. Smith Jr., 1995, “The Priority Structure of Corporate Liabilities," Journal of Finance 50(3), 899-917.

Berger, Allen N. and Gregory F. Udell, 1990, “Collateral, Loan Quality and Bank Risk,” Journal of Monetary Economics.

Berger, Allen N. and Gregory F. Udell, 1995, "Relationship Lending and Lines of Credit in Small Firm Finance," Journal of Business 68, 351-82.

Besanko, D. and Anjan Thakor, 1987, "Competitive Equilibrium in the Credit Market under Asymmetric Information," Journal of Economic Theory 42, 167-82.

Bester, H., 1985, "Screening v. Rationing in Credit Market with Imperfect Information," American Economic Review 75, 850-55.

Bhattacharya, Sudipto and Anjan Thakor, 1993, "Contemporary Banking Theory," Journal of Financial Intermediation 3, 2-50.

Boyd, John and Edward Prescott, 1986, "Financial Intermediary Coalitions," Journal of Economic Theory 38, 211-32.

Bryant, J., 1980, “A Model of Reserves, Bank Runs, and Deposit Insurance,” Journal of Banking and Finance 4, 335-44.

Carey, Mark, Mitch Post, and Steven A. Sharpe, 1998, "Does Corporate Lending by Banks and Finance Companies Differ? Evidence on Specialization in Private Debt Contracting," Journal of Finance, 53(3).

Chan, Y. and George Kanatas, 1985, "Asymmetric Valuations and the Role of Collateral in Loan Agreements," Journal of Money, Credit and Banking 17, 84-95.

Demsetz, Rebecca S., Marc R. Saidenberg and Philip E. Strahan, 1998, “Agency Problems and Risk-Taking at Banks,” Federal Reserve Bank of New York, Staff Report no. 9709.

Dennis, Steven and Donald J. Mullineaux, 1998, "Syndicated Loans," mimeo.

Diamond, Douglas, 1984, "Financial Intermediation and Delegated Monitoring," Review of Economic Studies 51, 393-414. 
Diamond, Douglas and Philip Dybvig, 1983, "Bank Runs, Deposit Insurance and Liquidity," Journal of Political Economy 91, 401-19.

Himmelberg, Charles P. and Donald P. Morgan, 1995, “Is Bank Lending Special?” in Is Bank Lending Important for the Transmission of Monetary Policy, edited buy Joe Peek and Eric Rosengren, Federal Reserve Bank of Boston, Conference Series no. 39.

Houston, Joel and Christopher James, 1996, "Bank Information Monopolies and the Mix of Private and Public Debt Claims," Journal of Finance 51(5), 1863-89.

Hubbard, Glenn R., Kenneth Kuttner and Darius Palia, 1998, “Are there Bank Effects in Borrowers' Costs of Funds? Evidence from a Matched Sample of Borrowers and Banks," mimeo, June 1998.

Leland, Hayne and David Pyle, 1977, "Informational Asymmetries, Financial Structure and Financial Intermediation," Journal of Finance 32, 371-87.

Lown, Cara and Stavros Peristiani, 1995, "The Behavior of Consumer Loan Rates during the 1990 Credit Slowdown,” Journal of Banking and Finance 20, 1673-94.

Mehran, Hamid, Robert A. Taggart and David Yermack, 1999, "CEO Ownership, Leasing and Debt Financing," forthcoming in Financial Management.

Morgan, Donald, 1995, "Bank Monitoring Reduces Agency Problems: New Evidence Using the Financial Covenants in Bank Loan Commitments," PaineWebber Working Paper Series no. PW-95-12, Columbia University Business School.

Petersen, Mitchell A. and Raghuram G. Rajan, 1994, “The Benefits of Firm-Creditor Relationships: Evidence from Small Business Data," Journal of Finance 49, 3-37.

Rajan, Raghuram and Andrew Winton, 1995, "Covenants and Collateral as Incentives to Monitor," Journal of Finance 50, 1113-46.

Ramakrishnan, Ram and Anjan Thakor, 1984, "Information Reliability and a Theory of Financial Intermediation, Review of Financial Studies 51, 415-32.

Saidenberg, Marc R. and Philip E. Strahan, 1999, “A re Banks Important for Financing Large Businesses?" mimeo.

Standard \& Poor's, 1999, “D efaults Increase M odestly in 1997," special report, A ugust 1998.

Stiglitz, Joseph E. and A. Weiss, 1981, "Credit Rationing in Markets with Incomplete Information," American Economic Review 71, 393-409.

VanDeCastle, Karen, 1999, "Recovering Your Money: Insights into Losses from Default," S\&P. 
Table 1: Mean Values for Facilities on the Loan Pricing Corporation's Dealscan Database, 1988-98

\begin{tabular}{llll}
\hline & $\begin{array}{l}\text { All } \\
\text { Observations }\end{array}$ & $\begin{array}{l}\text { Observations in } \\
\text { Compustat }\end{array}$ & $\begin{array}{l}\text { Observations } \\
\text { not in } \\
\text { Compustat }\end{array}$ \\
\cline { 2 - 4 } All Facilities (Loans) & & & \\
Number of Facilities & 57,782 & 27,230 & 30,552 \\
$\begin{array}{l}\text { Percent that are Lines of Credit } \\
\text { Percent that are Term Loans }\end{array}$ & 59.1 & 60.2 & 58.0 \\
Percent that are Other Loans & 32.9 & 30.7 & 34.8 \\
Lines of Credit & 8.0 & 9.1 & 7.2 \\
Drawn AIS & & & \\
Undrawn AIS & 186 & 187 & 184 \\
Loan Size (\$MM) & 33 & 32 & 34 \\
Percent Secured & 211 & 234 & 189 \\
Maturity (Months) & 78.0 & 76.0 & 47.3 \\
Term Loans & 42 & 39 & \\
Drawn AIS & & & 225 \\
Loan Size (\$MM) & 238 & 250 & 129 \\
Percent Secured & 126 & 122 & 84.5 \\
Maturity (Months) & 85.1 & 85.5 & 71 \\
\hline
\end{tabular}


Table 2: Average Loan Pricing by Borrower Size and Rating

\begin{tabular}{|c|c|c|c|}
\hline \multirow[b]{3}{*}{ Small Borrowers } & \multicolumn{2}{|c|}{ Lines of Credit: } & \multirow{2}{*}{$\begin{array}{l}\text { Term Loans: } \\
\text { Drawn Spread }\end{array}$} \\
\hline & Drawn Spread & Undrawn Spread & \\
\hline & & & \\
\hline Unrated Firms & 258 & 39 & 301 \\
\hline Investment Grade & $\mathrm{n} / \mathrm{a}$ & $\mathrm{n} / \mathrm{a}$ & $\mathrm{n} / \mathrm{a}$ \\
\hline Speculative Grade & 265 & 47 & 301 \\
\hline \multicolumn{4}{|l|}{ Large Borrowers } \\
\hline Unrated Firms & 188 & 33 & 251 \\
\hline Investment Grade & 47 & 14 & 118 \\
\hline Speculative Grade & 174 & 38 & 228 \\
\hline
\end{tabular}


Table 3: Mean and standard deviation for financial characteristics used to explain bank loan contract features

\begin{tabular}{|c|c|c|}
\hline & Lines of Credit & Term Loans \\
\hline Facility Size (MM\$s) & $\begin{array}{c}202 \\
(505)\end{array}$ & $\begin{array}{c}90 \\
(272)\end{array}$ \\
\hline Maturity (months) & $\begin{array}{c}38 \\
(23)\end{array}$ & $\begin{array}{c}56 \\
(29)\end{array}$ \\
\hline Secured Indicator & $\begin{array}{c}0.78 \\
(0.42)\end{array}$ & $\begin{array}{c}0.94 \\
(0.24)\end{array}$ \\
\hline Drawn AIS (bps) & $\begin{array}{c}182 \\
(134)\end{array}$ & $\begin{array}{c}261 \\
(132)\end{array}$ \\
\hline Undrawn AIS (bps) & $\begin{array}{c}32 \\
(21)\end{array}$ & - \\
\hline Market Value of Assets (MM\$s) & $\begin{array}{c}2423 \\
(7822)\end{array}$ & $\begin{array}{c}918 \\
(2,295)\end{array}$ \\
\hline EBITDA / Assets & $\begin{array}{c}0.11 \\
(0.17)\end{array}$ & $\begin{array}{c}0.10 \\
(0.16)\end{array}$ \\
\hline High interest Coverage Indicator & $\begin{array}{c}0.56 \\
(0.50)\end{array}$ & $\begin{array}{c}0.47 \\
(0.50)\end{array}$ \\
\hline Sales / Assets & $\begin{array}{c}1.34 \\
(0.88)\end{array}$ & $\begin{array}{c}1.32 \\
(0.89)\end{array}$ \\
\hline High Liquidity Indicator & $\begin{array}{c}0.54 \\
(0.50)\end{array}$ & $\begin{array}{c}0.52 \\
(0.50)\end{array}$ \\
\hline Unrated Indicator & $\begin{array}{c}0.67 \\
(0.47)\end{array}$ & $\begin{array}{c}0.79 \\
(0.41)\end{array}$ \\
\hline Speculative Grade Rating Indicator & $\begin{array}{c}0.17 \\
(0.37)\end{array}$ & $\begin{array}{c}0.17 \\
(0.37)\end{array}$ \\
\hline Leverage [Debt / (Debt+Market Capitalization)] & $\begin{array}{c}0.31 \\
(0.23)\end{array}$ & $\begin{array}{c}0.37 \\
(0.25)\end{array}$ \\
\hline Capitalized Leases / Debt & $\begin{array}{c}0.06 \\
(0.14)\end{array}$ & $\begin{array}{c}0.05 \\
(0.13)\end{array}$ \\
\hline Market-to-Book Asset Ratio & $\begin{array}{c}1.71 \\
(1.18)\end{array}$ & $\begin{array}{c}1.61 \\
(1.29)\end{array}$ \\
\hline $\begin{array}{l}\text { Tangible Assets [Net Property, Plant \& } \\
\text { Equipment+Inventories / Assets] }\end{array}$ & $\begin{array}{c}0.48 \\
(0.23)\end{array}$ & $\begin{array}{c}0.46 \\
(0.24)\end{array}$ \\
\hline
\end{tabular}


Table 4: Regressions relating firm financial characteristics to bank loan pricing

Dependent Variable = Loan Price

\begin{tabular}{|c|c|c|c|}
\hline & \multicolumn{2}{|c|}{ Lines of Credit } & \multirow{2}{*}{$\begin{array}{c}\text { Term Loans } \\
\text { Log of } \\
\text { Drawn AIS }\end{array}$} \\
\hline & $\begin{array}{c}\text { Log of } \\
\text { Drawn AIS }\end{array}$ & $\begin{array}{c}\text { Log of } \\
\text { Undrawn AIS }\end{array}$ & \\
\hline Log of Assets & $\begin{array}{l}-0.29 * \\
(0.01)\end{array}$ & $\begin{array}{l}-0.13^{*} \\
(0.01)\end{array}$ & $\begin{array}{l}-0.20 * \\
(0.01)\end{array}$ \\
\hline EBITDA / Assets & $\begin{array}{l}-0.20^{*} \\
(0.06)\end{array}$ & $\begin{array}{l}-0.24^{*} \\
(0.06)\end{array}$ & $\begin{array}{l}-0.25^{*} \\
(0.06)\end{array}$ \\
\hline High interest Coverage Indicator & $\begin{array}{l}-0.20^{*} \\
(0.02)\end{array}$ & $\begin{array}{l}-0.15^{*} \\
(0.02)\end{array}$ & $\begin{array}{l}-0.08^{*} \\
(0.03)\end{array}$ \\
\hline Sales / Assets & $\begin{array}{l}-0.05^{*} \\
(0.01)\end{array}$ & $\begin{array}{l}-0.02 * \\
(0.01)\end{array}$ & $\begin{array}{c}0.01 \\
(0.01)\end{array}$ \\
\hline High Liquidity Indicator & $\begin{array}{l}-0.01 \\
(0.01)\end{array}$ & $\begin{array}{l}0.06^{*} \\
(0.02)\end{array}$ & $\begin{array}{l}-0.06^{*} \\
(0.02)\end{array}$ \\
\hline Unrated Indicator & $\begin{array}{l}0.44^{*} \\
(0.03)\end{array}$ & $\begin{array}{l}0.46^{*} \\
(0.03)\end{array}$ & $\begin{array}{l}0.32 * \\
(0.09)\end{array}$ \\
\hline Speculative Grade Rating Indicator & $\begin{array}{l}0.47^{*} \\
(0.05)\end{array}$ & $\begin{array}{l}0.64^{*} \\
(0.02)\end{array}$ & $\begin{array}{l}0.43^{*} \\
(0.09)\end{array}$ \\
\hline $\begin{array}{l}\text { Leverage [Debt / (Debt+Market } \\
\text { Capitalization)] }\end{array}$ & $\begin{array}{l}0.47 * \\
(0.05)\end{array}$ & $\begin{array}{l}0.39^{*} \\
(0.05)\end{array}$ & $\begin{array}{l}0.41^{*} \\
(0.07)\end{array}$ \\
\hline Capitalized Leases / Debt & $\begin{array}{l}0.30^{*} \\
(0.05)\end{array}$ & $\begin{array}{l}0.21^{*} \\
(0.06)\end{array}$ & $\begin{array}{l}-0.05 \\
(0.13)\end{array}$ \\
\hline Market-to-Book Asset Ratio & $\begin{array}{l}0.08^{*} \\
(0.01)\end{array}$ & $\begin{array}{l}0.03^{*} \\
(0.01)\end{array}$ & $\begin{array}{l}0.05^{*} \\
(0.02)\end{array}$ \\
\hline $\begin{array}{l}\text { Tangible Assets [Net Property, Plant \& } \\
\text { Equipment+Inventories / Assets] }\end{array}$ & $\begin{array}{l}-0.13^{*} \\
(0.03)\end{array}$ & $\begin{array}{l}-0.03 \\
(0.03)\end{array}$ & $\begin{array}{l}-0.11^{*} \\
(0.05)\end{array}$ \\
\hline $\mathrm{N}$ & 6,057 & 4,796 & 2,435 \\
\hline R-Squared & 0.67 & 0.53 & 0.41 \\
\hline
\end{tabular}

Regression coefficients reported, with their standard errors below in parentheses. Regressions also include 1-digit SIC code indicators, indicators for each years (1988-98), and loan purpose indicators.

*Statistically significant at the 10 percent level. 
Table 5: Mean Drawn All-in Spread by Borrower Size, Rating, and Secured Status

\begin{tabular}{lcccc}
\hline & \multicolumn{2}{c}{ Lines of Credit: } & \multicolumn{2}{c}{ Term Loans: } \\
& Secured & Unsecured & Secured & Unsecured \\
\cline { 2 - 5 } Small Borrowers & & & & \\
Unrated Firms & 286 & 161 & 312 & 202 \\
Investment Grade & $\mathrm{n} / \mathrm{a}$ & $\mathrm{n} / \mathrm{a}$ & $\mathrm{n} / \mathrm{a}$ & $\mathrm{n} / \mathrm{a}$ \\
Speculative Grade & 304 & 201 & 318 & $\mathrm{n} / \mathrm{a}$ \\
Large Borrowers & & & & \\
Unrated Firms & 250 & 103 & 280 & 127 \\
Investment Grade & 141 & 37 & 183 & 79 \\
Speculative Grade & 219 & 86 & 243 & 166 \\
\hline
\end{tabular}

This table reports the mean drawn spread for loans by borrower size, rating and the presence of collateral. Small borrowers are those with total assets (debt plus market value of equity) above the median in the sample. N/A indicated that there were fewer than 10 loans in the cell. 
Table 5: Regressions relating firm financial characteristics to bank loan pricing, with non-price terms as regressors

Dependent Variable = Loan Price

\begin{tabular}{|c|c|c|c|}
\hline & \multicolumn{2}{|c|}{ Lines of Credit } & \multirow{2}{*}{$\begin{array}{c}\text { Term Loans } \\
\text { Log of } \\
\text { Drawn AIS }\end{array}$} \\
\hline & $\begin{array}{c}\text { Log of } \\
\text { Drawn AIS }\end{array}$ & $\begin{array}{c}\text { Log of } \\
\text { Undrawn AIS }\end{array}$ & \\
\hline Log of Loan Size & $\begin{array}{l}-0.06^{*} \\
(0.01)\end{array}$ & $\begin{array}{l}-0.01 \\
(0.01)\end{array}$ & $\begin{array}{l}-0.01 \\
(0.01)\end{array}$ \\
\hline Log of Contractual Maturity & $\begin{array}{l}-0.04 * \\
(0.01)\end{array}$ & $\begin{array}{l}0.15^{*} \\
(0.01)\end{array}$ & $\begin{array}{l}-0.03 * \\
(0.02)\end{array}$ \\
\hline Secured Indicator & $\begin{array}{l}0.51^{*} \\
(0.02)\end{array}$ & $\begin{array}{l}0.32 * \\
(0.02)\end{array}$ & $\begin{array}{l}0.49^{*} \\
(0.06)\end{array}$ \\
\hline Secured Missing Indicator & $\begin{array}{l}0.09^{*} \\
(0.02)\end{array}$ & $\begin{array}{l}0.12 * \\
(0.02)\end{array}$ & $\begin{array}{l}0.23^{*} \\
(0.06)\end{array}$ \\
\hline Log of Total Assets & $\begin{array}{l}-0.19^{*} \\
(0.01)\end{array}$ & $\begin{array}{l}-0.10^{*} \\
(0.01)\end{array}$ & $\begin{array}{l}-0.17^{*} \\
(0.01)\end{array}$ \\
\hline EBITDA / Assets & $\begin{array}{l}-0.15^{*} \\
(0.05)\end{array}$ & $\begin{array}{l}-0.25^{*} \\
(0.06)\end{array}$ & $\begin{array}{l}-0.21 * \\
(0.06)\end{array}$ \\
\hline High interest Coverage Indicator & $\begin{array}{l}-0.17 * \\
(0.02)\end{array}$ & $\begin{array}{l}-0.14 * \\
(0.02)\end{array}$ & $\begin{array}{l}-0.06^{*} \\
(0.03)\end{array}$ \\
\hline Sales / Assets & $\begin{array}{l}-0.03 * \\
(0.01)\end{array}$ & $\begin{array}{l}-0.01 \\
(0.01)\end{array}$ & $\begin{array}{c}0.01 \\
(0.01)\end{array}$ \\
\hline High Liquidity Indicator & $\begin{array}{c}0.01 \\
(0.01)\end{array}$ & $\begin{array}{l}0.04 * \\
(0.01)\end{array}$ & $\begin{array}{l}-0.04 * \\
(0.02)\end{array}$ \\
\hline Unrated Indicator & $\begin{array}{l}0.38^{*} \\
(0.03)\end{array}$ & $\begin{array}{l}0.42 * \\
(0.02)\end{array}$ & $\begin{array}{l}0.22 * \\
(0.09)\end{array}$ \\
\hline Speculative Grade Rating Indicator & $\begin{array}{l}0.56^{*} \\
(0.03)\end{array}$ & $\begin{array}{l}0.59^{*} \\
(0.02)\end{array}$ & $\begin{array}{l}0.34^{*} \\
(0.09)\end{array}$ \\
\hline $\begin{array}{l}\text { Leverage [Debt / (Debt+Market } \\
\text { Capitalization)] }\end{array}$ & $\begin{array}{l}0.39^{*} \\
(0.04)\end{array}$ & $\begin{array}{l}0.28^{*} \\
(0.05)\end{array}$ & $\begin{array}{l}0.45^{*} \\
(0.06)\end{array}$ \\
\hline
\end{tabular}


Table 5 (Continued)

Capitalized Leases / Debt

Market-to-Book Asset Ratio

Tangible Assets [Net Property, Plant \& Equipment+Inventories / Assets]

\begin{tabular}{ccc}
\multicolumn{2}{c}{ Lines of Credit } & Term Loans \\
\hline $\begin{array}{c}\text { Log of } \\
\text { Drawn AIS }\end{array}$ & $\begin{array}{c}\text { Log of } \\
\text { Undrawn AIS }\end{array}$ & $\begin{array}{c}\text { Log of } \\
\text { Drawn AIS }\end{array}$ \\
\hline $0.25^{*}$ & $0.20^{*}$ & -0.10 \\
$(0.05)$ & $(0.06)$ & $(0.13)$ \\
$0.06^{*}$ & $0.02^{*}$ & $0.08^{*}$ \\
$(0.01)$ & $(0.01)$ & $(0.01)$ \\
$-0.06^{*}$ & 0.01 & -0.06 \\
$(0.03)$ & $(0.03)$ & $(0.05)$ \\
\hline 5,779 & 4,690 & 2,282 \\
0.72 & 0.57 & 0.45 \\
\hline
\end{tabular}

$\mathrm{N}$

R-Squared

0.72

0.57

Regression coefficients reported, with their standard errors below in parentheses. Regressions also include 1-digit SIC code indicators, indicators for each years (1988-98), and loan purpose indicators.

*Statistically significant at the 10 percent level. 
Table 6: Regressions relating firm financial characteristics to non-price terms of bank loan contracts

Panel A: Dependent Variable $=$ Log of Facility Size

\begin{tabular}{lcc}
\hline & Lines of Credit & Term Loans \\
\cline { 2 - 3 } Log of Total Assets & $0.73^{*}$ & $0.81^{*}$ \\
& $(0.01)$ & $(0.02)$ \\
EBITDA / Assets & $0.14^{*}$ & 0.24 \\
High interest Coverage Indicator & $(0.08)$ & $(0.16)$ \\
& 0.02 & $0.12^{*}$ \\
Sales / Assets & $(0.03)$ & $(0.06)$ \\
& $0.16^{*}$ & 0.05 \\
High Liquidity Indicator & $(0.02)$ & $(0.03)$ \\
& $0.13^{*}$ & -0.01 \\
Unrated Indicator & $(0.03)$ & $(0.05)$ \\
Speculative Grade Rating Indicator & $-0.19^{*}$ & $0.26^{*}$ \\
& $(0.05)$ & $(0.14)$ \\
Leverage [Debt / (Debt+Market Capitalization)] & $-0.10^{*}$ & 0.18 \\
& $(0.05)$ & $(0.14)$ \\
Capitalized Leases / Debt & $0.37^{*}$ & $0.30^{*}$ \\
Market-to-Book Asset Ratio & $(0.09)$ & $(0.14)$ \\
Tangible Assets [Net Property, Plant \& & $-0.26^{*}$ & 0.01 \\
Equipment+Inventories / Assets] & $(0.10)$ & $(0.15)$ \\
N & $-0.18^{*}$ & $-0.12^{*}$ \\
R-Squared & $(0.02)$ & $(0.04)$ \\
Regresson Coeffici & $0.01^{*}$ \\
& $0.28^{*}$ & $(0.10)$ \\
\hline & $(0.06)$ & 2,435 \\
& 6,057 & 0.69 \\
\hline
\end{tabular}

Regression coefficients reported, with their standard errors below in parentheses. Regressions also include 1-digit SIC code indicators, indicators for each years (1988-98), and loan purpose indicators.

*Statistically significant at the 10 percent level. 
Table 6: Regressions relating firm financial characteristics to non-price terms of bank loan contracts

Panel B: Dependent Variable = 1 of Loan is Secured

\begin{tabular}{|c|c|c|}
\hline & Lines of Credit & Term Loans \\
\hline Log of Total Assets & $\begin{array}{l}-0.10^{*} \\
(0.01)\end{array}$ & $\begin{array}{l}-0.02 * \\
(0.01)\end{array}$ \\
\hline EBITDA / Assets & $\begin{array}{l}-0.25^{*} \\
(0.07)\end{array}$ & $\begin{array}{l}-0.02 \\
(0.05)\end{array}$ \\
\hline High interest Coverage Indicator & $\begin{array}{l}-0.05^{*} \\
(0.02)\end{array}$ & $\begin{array}{l}-0.01 \\
(0.01)\end{array}$ \\
\hline Sales / Assets & $\begin{array}{l}-0.02 * \\
(0.01)\end{array}$ & $\begin{array}{l}-0.01 \\
(0.01)\end{array}$ \\
\hline High Liquidity Indicator & $\begin{array}{c}0.01 \\
(0.01)\end{array}$ & $\begin{array}{l}-0.014 * \\
(0.008)\end{array}$ \\
\hline Unrated Indicator & $\begin{array}{l}0.15^{*} \\
(0.03)\end{array}$ & $\begin{array}{l}0.04 * \\
(0.03)\end{array}$ \\
\hline Speculative Grade Rating Indicator & $\begin{array}{l}0.13^{*} \\
(0.02)\end{array}$ & $\begin{array}{c}0.02 \\
(0.01)\end{array}$ \\
\hline Leverage [Debt / (Debt+Market Capitalization)] & $\begin{array}{l}0.37 * \\
(0.05)\end{array}$ & $\begin{array}{l}0.07 * \\
(0.02)\end{array}$ \\
\hline Capitalized Leases / Debt & $\begin{array}{l}-0.01 \\
(0.04)\end{array}$ & $\begin{array}{c}0.02 \\
(0.03)\end{array}$ \\
\hline Market-to-Book Asset Ratio & $\begin{array}{l}0.04 * \\
(0.01)\end{array}$ & $\begin{array}{c}0.01 \\
(0.01)\end{array}$ \\
\hline $\begin{array}{l}\text { Tangible Assets [Net Property, Plant \& } \\
\text { Equipment+Inventories / Assets] }\end{array}$ & $\begin{array}{l}-0.09^{*} \\
(0.01)\end{array}$ & $\begin{array}{l}-0.03 * \\
(0.02)\end{array}$ \\
\hline $\begin{array}{l}\mathrm{N} \\
\text { Pseudo R-Squared }\end{array}$ & $\begin{array}{c}3,731 \\
0.34\end{array}$ & $\begin{array}{c}1,823 \\
0.19\end{array}$ \\
\hline
\end{tabular}

The regression is estimated as a univariate probit. The coefficients reported indicate the effect of a unit change in the explanatory variable from its sample mean on the probability of a loan being secured, with their standard errors below in parentheses. Regressions also include 1-digit SIC code indicators, indicators for each years (1988-98), and loan purpose indicators.

*Statistically significant at the 10 percent level. 
Table 6: Regressions relating firm financial characteristics to non-price terms of bank loan contracts

Panel C: Dependent Variable = Log of Maturity

\begin{tabular}{lcc}
\hline & Lines of Credit & Term Loans \\
\cline { 2 - 3 } Log of Total Assets & $0.07^{*}$ & $0.07^{*}$ \\
EBITDA / Assets & $(0.01)$ & $(0.01)$ \\
& $0.34^{*}$ & $0.25^{*}$ \\
High interest Coverage Indicator & $(0.10)$ & $(0.12)$ \\
& -0.02 & $0.09^{*}$ \\
Sales / Assets & $(0.03)$ & $(0.04)$ \\
& -0.01 & 0.03 \\
High Liquidity Indicator & $(0.01)$ & $(0.02)$ \\
& $0.19^{*}$ & $0.08^{*}$ \\
Unrated Indicator & $(0.02)$ & $(0.03)$ \\
Speculative Grade Rating Indicator & $0.11^{*}$ & $0.16^{*}$ \\
& $(0.04)$ & $(0.09)$ \\
Leverage [Debt / (Debt+Market Capitalization)] & $0.11^{*}$ & $0.22^{*}$ \\
Capitalized Leases / Debt & $(0.04)$ & $(0.09)$ \\
Market-to-Book Asset Ratio & $0.30^{*}$ & 0.02 \\
Tangible Assets [Net Property, Plant \& & $(0.06)$ & $(0.09)$ \\
Equipment+Inventories / Assets] & $-0.12^{*}$ & -0.13 \\
R-Squared & $(0.06)$ & $(0.14)$ \\
\hline
\end{tabular}

Regression coefficients reported, with their standard errors below in parentheses. Regressions also include 1-digit SIC code indicators, indicators for each years (1988-98), and loan purpose indicators.

*Statistically significant at the 10 percent level. 


\section{Appendix I: What Firms Appear on Dealscan?}

LPC focuses on the syndicated loan market, and its data collection procedure may bias the sample toward the larger, better established firms. ${ }^{21}$ To check whether the firms appearing in Dealscan are representative of all firms on Compustat, I compare the firm attributes mentioned above for year-end 1997 for Compustat firms that appear in Dealscan at some point over the 1988 to 1998 period with those Compustat firms that do not appear on Dealscan.

Dealscan firms are much larger and more profitable than the other Compustat firms (Table Appendix Table 1). The median market capitalization of the Dealscan firms (\$265 million) exceeds the median market capitalization of other firms by a factor of more than four. The Dealscan firms earned a 12 percent return on assets, while the other firms earned only seven percent; the Dealscan firms also had higher median interest coverage ratios and sales-to-assets ratios. Rated firms are also more likely to appear on Dealscan, as are firms with more tangible assets.

These results suggest that the selection criteria LPC uses to construct Dealscan favor larger, better-established and more profitable firms and suggests that the results relating firm characteristics to loan contract features should be viewed with caution. Among the wellestablished and profitable firms, however, it is the ones with a greater demand for bank credit that are more likely to appear on Dealscan. In particular, firms with greater leverage are more likely to appear on Dealscan. Of course, it is not too surprising that Dealscan firms would have aboveaverage levels of debt since all of them borrow from banks. ${ }^{22}$

\footnotetext{
${ }^{21}$ One of LPC's primary sources is data self-reported to them by lenders. Large loan syndicators have a strong incentive to report information because LPC publicizes the rankings of the top syndicators. Since these large syndicators tend to lend to large borrowers, the large borrowers are likely to be over represented in Dealscan.

${ }^{22}$ have also looked at the relationship between these firm characteristics and the probability of appearing in Dealscan in a multivariate probit. The results are similar to those in the univariate setting and are omitted to enhance the clarity of the presentation.
} 


\begin{tabular}{lll} 
& $\begin{array}{l}\text { Compustat } \\
\text { Observations in } \\
\text { Dealscan }\end{array}$ & $\begin{array}{l}\text { Compustat } \\
\text { Observations not in } \\
\text { Dealscan }\end{array}$ \\
\cline { 2 - 3 } Total Assets (\$MM) & 278 & 63 \\
Market Capitalization (\$MM) & 265 & 66 \\
EBITDA / Assets & 0.12 & 0.07 \\
EBITDA / Interest Expenses & 5.1 & 2.9 \\
Sales / Assets & 0.98 & 0.61 \\
Percent Unrated & 70.0 & 91.3 \\
Percent of Rated that are Investment Grade & 49.8 & 62.5 \\
Percent of Rated that are Speculative Grade & 50.2 & 37.5 \\
Leverage [Debt / (Debt+Market Capitalization)] & 0.21 & 0.09 \\
Market-to-Book Asset Ratio & 1.49 & 1.47 \\
Tangible Assets [Property, Plant \& Equipment / & 0.24 & 0.11 \\
Assets] & & 4,197 \\
N & 4,253 & \\
\hline
\end{tabular}

